\title{
MODELE DOJRZAŁOŚCI PROCESOWEJ ORGANIZACJI
}

Z a r y s t r e ś c i: W artykule poruszono problematykę dojrzałości procesowej organizacji. Przedstawiono jej istotę oraz pokazano różnice między organizacją dojrzałą i niedojrzałą procesowo. Zaprezentowano wybrane modele dojrzałości procesowej organizacji, zarówno te jednowymiarowe, jak i te wykorzystujące holistyczne podejście (wielowymiarowe). Szczególnie miejsce poświęcono modelom dojrzałości procesowej organizacji publicznych.

$\mathrm{S} \nmid$ o w a k 1 u c z o w e: dojrzałość procesowa organizacji, modele dojrzałości procesowej organizacji, modele dojrzałości procesowej organizacji publicznych.

K 1 a s y fik a c j J E L: L 21

\section{WSTĘP}

Problematyka dojrzałości procesowej organizacji zyskuje coraz większą popularność w badaniach naukowych, a wiedza na temat sposobów jej pomiaru i korzyści otrzymywanych dzięki przechodzeniu na coraz wyższe jej poziomy wykorzystywana jest z powodzeniem w praktyce zarządzania organizacjami.

Rosnąca popularność tej tematyki wyraża się m.in. w mnogości artykułów naukowych poświęconych dojrzałości procesowej², a także w narastającej ilości badań klasyfikujących organizacje na poszczególnych poziomach dojrzało-

\footnotetext{
* Adres do korespondencji: Magdalena Raczyńska, Uniwersytet Warmińsko-Mazurski w Olsztynie, Wydział Nauk Ekonomicznych, Katedra Organizacji i Zarządzania, al. Michała Oczapowskiego 2, Olsztyn, e-mail: misiewicz.magdalena@gmail.com;

${ }^{2}$ Przykładowo, A. Tarhan, O. Turetken i H. A. Reijers dokonali przeglądu literatury poświęconej problematyce dojrzałości procesowej w latach 1990 - 2014, w konsekwencji poddając analizie 2899 pozycji literaturowych [ Tarhan i in., 2016, s. 122].
} 
ści procesowej, identyfikujących jej determinanty, czy proponujących coraz to nowsze modele.

Pomimo istnienia niemalże kilkuset modeli dojrzałości procesowej o różnym zakresie i szczegółowości, wciąż znaleźć można miejsce na nowe propozycje [Kalinowski, 2011, s. 179; Rosemann, de Bruin, 2005, s. 2]. Argumentem za tworzeniem kolejnych może być fakt, iż większość z dostępnych modeli dojrzałości procesowej jest jednowymiarowa, tzn. bazuje głównie na ocenie dojrzałości procesów identyfikowanych w organizacjach, pomijając inne istotne obszary, które mogą wpływać na poziom dojrzałości procesowej i warunkować sposób jej pomiaru.

W ostatnich latach problem ten zaczął zyskiwać na znaczeniu, co poskutkowało wykształceniem się takich modeli dojrzałości procesowej, które uznać można za wielowymiarowe, tzn. uwzględniające, poza obszarem procesów, rownież inne sfery tj. m.in. kultura organizacyjna, strategia, zasoby ludzkie, mechanizmy kontroli, metody i techniki, orientacja procesowa czy IT ${ }^{1}$.

Zupełnie osobną kwestią pozostaje pomiar dojrzałości procesowej organizacji publicznych. Poprzez specyfikę uwarunkowań funkcjonowania tychże organizacji, problem doboru odpowiedniego narzędzia wysuwa się na pierwszy plan. W rezultacie, istnieje niewiele modeli dojrzałości procesowej dedykowanych stricte organizacjom publicznym, co stanowić może pole do popisu dla badaczy zgłębiających tę tematykę. Podjęta została ona także w niniejszym artykule, gdzie przedstawiono wybrane modele dojrzałości procesowej organizacji, w tym modele dojrzałości organizacji publicznych.

\section{ISTOTA DOJRZAŁOŚCI PROCESOWEJ ORGANIZACJI}

Charakter definicji dojrzałości procesowej organizacji zależny jest w głównej mierze od tego, czy ujmowana jest ona jedno czy wielowymiarowo. Jak wspomniano we wstępie, większość modeli dojrzałości procesowej opiera się przede wszystkim na istniejących $\mathrm{w}$ danej organizacji procesach, a osiągany poziom dojrzałości procesowej określa zaawansowanie danej organizacji w realizacji (wdrożeniu) koncepcji zarządzania procesami. Dojrzałość procesowa dotyczy więc głównie stopnia i zakresu realizacji koncepcji zarządzania procesami w organizacji, poprzez stosowanie charakterystycznych dla niej metod i technik [Bitkowska, 2009, s. 155; Krukowski, 2016, s. 147]. Podając za P. Grajewskim, dojrzałość procesową można wyrazić zakresem w jakim procesy są formalnie zdefiniowane, zarządzane, elastyczne, mierzone i efektywne [Grajewski, 2007,

${ }^{1}$ Przykładowo, wielowymiarowy model dojrzałości procesowej przedstawił w 2004 r. D. M. Fisher, a w 2009 firma konsultingowa Gartner Group zaproponowała swój Gartner's Process Maturity Model (przyp. autora). 
s. 119]. Można ją również postrzegać jako pewną świadomość, że organizację tworzą horyzontalnie zachodzące w niej procesy, którymi należy w odpowiedni sposób zarządzać, tak aby zarówno procesy, jak i cała organizacja systematycznie dostarczały coraz lepszych rezultatów działalności [Brajer-Marczak, 2010, s. 516; Rosemann, de Bruin, 2005, s. 2]. Dojrzałość procesowa jest ponadto zdolnością organizacji do efektywnego kontrolowania jej procesów, przejawiającego się w ich definiowaniu, implementowaniu i mierzeniu, a także w dokonywaniu systematycznych decyzji usprawniających, bazujących na pomiarach wyników organizacji [Gabryelczyk, 2016, s. 3].

Uznaje się, iż w organizacjach, które można uznać za dojrzałe procesowo w pełni, m.in. zdolność do budowy i usprawniania produktów/usług jest cechą organizacji, a nie indywidualnych pracowników, procesy są w pełni zidentyfikowane a prace związane z projektowaniem procesów są zaplanowane. Cechy odróżniające organizacje procesowo dojrzałe od organizacji procesowo niedojrzałych zostały ujęte w tabeli 1 .

W podobny sposób czynniki ukazujące cechy niskiej i wysokiej dojrzałości procesowej wskazane zostały przez M. Rosemann'a i T. de Bruin. Według autorów, organizacje charakteryzujące się niskim stopniem (poziomem) dojrzałości procesowej realizują nieskoordynowane i pojedyncze projekty, zarządzanie ma charakter reaktywny i oparte jest na kluczowej kadrze, definiowane są głównie procesy standardowe, które powtarzane są na podstawie instrukcji, występują niskie kwalifikacje pracowników w zakresie wdrażania zarządzania procesowego, a organizację uznać można za statyczną. Z kolei, za organizację o cechach pełnej dojrzałości procesowej uznali taką, w której działania z zakresu zarządzania procesami są skoordynowane, pracownicy legitymują się wysoką wiedzą w zakresie zarządzania procesami, a także wykazują pełne zrozumienie w definiowaniu procesów, występuje automatyzacja powtarzalnych procesów, a organizację można uznać za innowacyjną [Rosemann, de Bruin, 2005, s. 5].

Proces osiągania pełnej dojrzałości procesowej przez organizacje utożsamiany jest $\mathrm{z}$ realizowaniem przez nie pewnych założeń dla poszczególnych poziomów w modelach dojrzałości procesowej. Poziomy te tworzą przewidywaną, pożądaną lub logiczną ścieżkę od stanu początkowego do dojrzałości, a wymogi odnośnie realizacji danych kryteriów na konkretnych poziomach mogą się różnić w przypadku odrębnych modeli dojrzałości procesowej [Röglinger, Pöppelbuß, Becker, 2012, s. 329]. 
Tabela 1. Cechy dojrzałości i niedojrzałości procesowej organizacji

\begin{tabular}{|c|c|}
\hline Cechy organizacji dojrzalych procesowo & Cechy organizacji niedojrzałych procesowo \\
\hline $\begin{array}{l}\text { Zdolność do budowy i usprawniania } \\
\text { produktu/usługi jest cechą organizacji, a nie } \\
\text { indywidualnych pracowników }\end{array}$ & $\begin{array}{l}\text { Duże uzależnienie od możliwości indywidualnych } \\
\text { pracowników }\end{array}$ \\
\hline $\begin{array}{l}\text { Procesy są w pełni zidentyfikowane, } \\
\text { a wiedza o nich jest skutecznie } \\
\text { przekazywana pracownikom }\end{array}$ & $\begin{array}{c}\text { Efektywność procesów może być przewidywalna } \\
\text { najwyżej na poziomie indywidualnego projektu, a nie } \\
\text { w ramach całej organizacji }\end{array}$ \\
\hline $\begin{array}{l}\text { Prace związane z projektowaniem procesów } \\
\text { są planowane }\end{array}$ & $\begin{array}{c}\text { Improwizacja procesów przez pracowników } \\
\text { i menedżerów }\end{array}$ \\
\hline $\begin{array}{l}\text { Procesy obserwuje się i usprawnia także za } \\
\text { pomoca kontrolowanych eksperymentów } \\
\text { i analizy relacji kosztu do osiaganego efektu }\end{array}$ & Wyspecyfikowane procesy nie są przestrzegane \\
\hline $\begin{array}{l}\text { Podział ról i odpowiedzialności jest jasno } \\
\text { zdefiniowany w ramach organizacji } \\
\text { poszczególnych projektów }\end{array}$ & $\begin{array}{l}\text { Występuje reakcyjne zarzadzanie (doraźne } \\
\text { reagowanie na pojawiające się kryzysy }\end{array}$ \\
\hline $\begin{array}{l}\text { Jakość produktów illub usług, a także } \\
\text { stopień zadowolenia klientów podlegają } \\
\text { monitorowaniu }\end{array}$ & $\begin{array}{c}\text { Harmonogram i budżet są zwykle przekraczane, } \\
\text { ponieważ nie są oparte na stabilnym przebiegu } \\
\text { procesów }\end{array}$ \\
\hline \multirow[t]{2}{*}{$\begin{array}{l}\text { Istnieje obiektywna, ilościowa baza do oceny } \\
\text { jakości produktów, usług i działania }\end{array}$} & $\begin{array}{l}\text { Przy niezmiennych ograniczeniach harmonogramu } \\
\text { i budżetu ich egzekwowanie odbywa się kosztem } \\
\text { jakości i funkcjonalności produktu illub usługi }\end{array}$ \\
\hline & $\begin{array}{l}\text { Nie ma sformalizowanych i obiektywnych kryteriów } \\
\text { oceny produktu, jakości i procesu oraz wczesnej } \\
\text { identyfikacji problemów (nieprzewidywalność jakości } \\
\text { produktu illub usługi) }\end{array}$ \\
\hline
\end{tabular}

Źródło: opracowanie własne na podstawie [Grajewski, 2007, s. 119-120].

\section{WYBRANE MODELE DOJRZAŁOŚCI PROCESOWEJ ORGANIZACJI}

Formalnie uznawaną definicję modeli dojrzałości organizacji przedstawili w 2009 r. M. Kohlegger, R. Maier i S. Thalmann. Autorzy stwierdzili, że modele dojrzałości koncepcyjnie reprezentują ilościowo lub jakościowo etapy rosnącej zdolności elementów modelu do wykonania stawianych zadań w celu ich oceny w odniesieniu do zdefiniowanych obszarów [Kohlegger i in., 2009, s. 54]. W kontekście modeli dojrzałości procesowej, wspomnianym obszarem może być obszar procesów (w przypadku modeli jednowymiarowych) lub inne, w których zidentyfikować można czynniki warunkujące osiąganie dojrzałości procesowej przez organizacje (przy rozpatrywaniu modeli wielowymiarowych). 
Modele dojrzałości procesowej można podzielić na takie, które odnoszą się do stanu poszczególnych procesów w organizacji oraz te, które dotyczą dojrzałości procesowej organizacji jako całości [Röglinger, Pöppelbuß, 2012, s. 7]. Przykładem modelu, który zaliczyć można do pierwszej grupy, na którym wzorowana była duża część modeli dojrzałości procesowej, jest model CMM (Capability Maturity Model). Podstawą dla wykształcenia się tego modelu była książka Managing the Software Proces W. Humpreya z 1989 r., w której opisał on po raz pierwszy zasady oceny dojrzałości procesów [Grela, 2013, s. 172]. Model CMM powstał bezpośrednio na zamówienie Departamentu Obrony USA, który wobec niezadowolenia z jakości dostarczanych produktów informatycznych, zlecił opracowanie listy referencyjnej, która pomogłaby oceniać zdolność firm wytwarzających oprogramowanie do realizacji zamówien rządowych. Zaproponowane podejście okazało sie, proste i skuteczne, szybko więc zaadaptowano CMM (poprzez tworzenie jego kolejnych wersji) do oceny firm działających w innych branżach [Chrapko, 2011, s. 1-3; Bitkowska i in., 2011, s. 65]. Wraz z ewolucją modelu, w roku 2001, powstała koncepcja CMMI (CMM Integration) zakładająca istnienie dwóch podejść (stopniowego i ciągłego) w kształtowaniu dojrzałości procesowej organizacji [Jurczuk, 2013, s. 13].

Model CMMI wyróżnia pięć poziomów dojrzałości procesowej [Brajer-Marczak, 2012, s. 516; Jurczuk, 2013, s. 13]:

Poziom 1 - tzw. poziom początkowy, na którym m.in. procesy są przypadkowe, nie występuje świadomość, że czynności realizowane w organizacji tworzą procesy (procesy nie są zidentyfikowane), nie funkcjonuje kategoria klienta wewnętrznego, a dominującym podejściem do zarządzania jest podejście funkcjonalne.

Poziom 2 - tzw. poziom powtarzalny, na którym procesy są powtarzalne, ale niezidentyfikowane, nieopisane i niemierzone. $\mathrm{W}$ organizacjach znajdujących się na tym poziomie można zauważyć istnienie świadomości procesów zachodzących w organizacji, zaczyna się także rozumieć istotę klienta wewnętrznego. Procesy nie są jednak w żaden sposób dokumentowane.

Poziom 3 - tzw. poziom zdefiniowany, na którym procesy są zidentyfikowane i opisane, ale nie są mierzone. Ponadto, występuje pełna świadomość występowania procesów, a także są one dokumentowane.

Poziom 4 - tzw. poziom zarządzany ilościowo, na którym procesy są zidentyfikowane, opisane, mierzone, dokumentowane, planowane i monitorowane, ale nie zarządzane. Oznacza to, iż informacje pochodzące z pomiarów procesów nie są wykorzystywane w procesie podejmowania decyzji zarządczych.

Poziom 5 - tzw. poziom optymalny, na którym procesy są zidentyfikowane, opisane, mierzone, dokumentowane, planowane, monitorowane i zarządzane.

Model CMMI stanowił inspirację m.in. do stworzenia modelu Business Process Maturity Model (BPMM) rozwijanego przez stowarzyszenie Object 
Management Group (OMG). W modelu tym, podobnie jak w modelu CMMI, zidentyfikowano 5 poziomów dojrzałości procesowej organizacji. W odróżnieniu do poziomów wyszczególnionych w modelu CMMI, poziomy w modelu BPMM odnoszą się nie tylko do aspektu procesów, ale skupiają się na sposobie zarządzania i podstawowym, postawionym celu. Wyróżniamy więc [Krukowski, 2016, s. 158; Lee i in., 2007, s. 10]:

Poziom 1, tzw. „początkowy” charakteryzujący się doraźnością zarządzania (zarządzanie ,ad hoc”) i brakiem konkretnych celów. Na tym poziomie to nie zarządzanie procesami, a kompetencje i zaangażowanie pracowników stanowią o sukcesie organizacji.

Poziom 2, tzw. „zarządzany”, na którym celem staje się stworzenie podstaw do zarządzania procesami w każdej jednostce lub projekcie.

Poziom 3, tzw. „standaryzowany”, dla którego charakterystyczne staje się stworzenie i używanie wspólnej organizacyjnej infrastruktury procesów, aby uzyskać spójność oferowanych produktów/usług.

Poziom 4, tzw. ,przewidywalny”, na którym celem jest wykorzystanie zdolności organizacyjnej infrastruktury procesów i aktywów procesowych poprzez zarządzanie nimi, by osiągnąc przewidywalne rezultaty.

Poziom 5, tzw. „innowacyjny”, charakteryzujący się ciągłym doskonaleniem procesów i produktów/usług organizacji, a także zapobieganiem problemom i zapewnianiem ciągłej zdolności do innowacyjnych usprawnień.

Odmienną grupą modeli są te, które prezentują bardziej wielowymiarowe, holistyczne podejście do dojrzałości procesowej organizacji. Przy jej ocenie nie koncentrują się bowiem tylko na aspekcie samych procesów (jak np. w modelu CMMI), ale uwzględniają też inne obszary (np. kultura organizacyjna, metody zarządzania, technologie informacyjne, strategia itd.), uznając je za krytyczne w osiąganiu następujących po sobie poziomów dojrzałości procesowej.

Przykładem takiego modelu jest model zaproponowany m.in. przez M. Hammera, D. M. Fishera czy Grupę Gartner.

W swoim modelu Dojrzałości Procesów i Przedsiębiorstwa (Process and Entreprise Maturity Model, PEMM) M. Hammer zidentyfikował i zdefiniował cztery poziomy czynników umożliwiających realizację procesów (P-1, P-2, P-3 i P-4), z których każdy kolejny opiera się na poprzednim. Czynniki te determinują stopnień dojrzałości konkretnego procesu, co można rozumieć jako jego zdolność do dostarczania optymalnych wyników i sprawnego funkcjonowania w dłuższym okresie. Zaliczono do nich:

Projekt - obejmuje kompleksowe podejście do opisu sposobu realizacji (wykonania) procesu, poprzez stopień sprecyzowania celu, znajomość oczekiwan klientów oraz zakres przygotowanej dokumentacji dla procesu. 
Wykonawców - odnosi się do wiedzy i umiejętności pracowników będących uczestnikami procesu, a także do stopnia ich samodzielności i otwartości na wprowadzanie zmian.

Właściciela procesu - czyli osobe ponosząca odpowiedzialność za proces i jego rezultaty od początku do końca, z uwzględnieniem jej pozycji w hierarchii organizacyjnej, zakresu władzy i odpowiedzialności.

Infrastrukture - czyli m.in. wykorzystywane systemy informatyczne wspomagające realizację procesu.

Mierniki - czyli wykorzystywane w przedsiębiorstwie sposoby pomiaru wyników oraz zestaw wskaźników wykorzystywanych do oceny efektywności procesu, a także umiejętności ich praktycznego stosowania.

Druga grupa czynników dotyczy zdolności organizacji, i w niej także wyróżniamy 4 poziomy (E1, E2, E3, E4). Twórca modelu stwierdził, ze nie wszystkie organizacje sa przygotowane do wykorzystania wymienionych wcześniej czynników umożliwiających realizację procesu, a te, które to potrafia, posiadaja kluczowe zdolności organizacyjne, przejawiajace sie, poprzez [Hammer, 2007, s. 112-121]:

Przywództwo - czyli wspieranie przebiegu procesu przez kadre kierowniczą. Kulture organizacyjną uwzględniająca m.in. koncentrację na kliencie, pracę zespołową, odpowiedzialność osobistą i akceptację zmian.

Kompetencje - dotyczące niezbędnych umiejętności w zakresie projektowania procesów, przejawiajace sie c poziomem wiedzy i umiejętności pracowników w zakresie zarządzania procesami, a także wyrażające się poprzez stosowaną w organizacji metodologię wprowadzania zmian w tym obszarze.

Nadzór - obejmujący mechanizmy zarządzania złożonymi projektami i inicjatywami w ramach stosowanego modelu procesu, podziału odpowiedzialności oraz stopnia integracji procesów zarówno wewnątrz firmy, jak i z uwzględnieniem działań podejmowanych przez klientów.

Ciekawym, wielowymiarowym modelem dojrzałości procesowej jest ten zaprezentowany przez D. M. Fishera. Autor przedstawił zależności między wynikami osiąganymi w poszczególnych obszarach stanowiących trzon większości organizacji, a poziomem dojrzałości procesowej organizacji (wyróżnił poziom silosu, poziom taktycznie zintegrowany, poziom oparty na procesach, poziom zoptymalizowany i poziom inteligentnie pracującej sieci). D. M. Fisher badaniom poddał pięć obszarów (nazwał je pięcioma dźwigniami zmian), do których zaliczył strategię, kontrolę, proces (orientację procesową), pracowników i technologię informacyjną. W rezultacie model D. M. Fishera pozwala na identyfikację barier i stymulatorów, które pojawiają się w wymienionych obszarach, i które mają wpływ na rozwój procesowy organizacji [Fisher, 2004, s. 1-7].

Na podobnych prawach do modelu D. M. Fishera swój model zaproponowała Grupa Gartner. W wersji modelu z 2008 r. założono istnienie sześciu pozio- 
mów dojrzałości procesowej (nazwano je fazami), na które wpływ mają wyniki osiągane $\mathrm{w}$ pięciu obszarach, $\mathrm{tj}$. zachowania organizacyjne, zasoby ludzkie, zarządzanie, metody i techniki oraz technologia informacyjna ${ }^{2}$. Przykładowo, rozpatrując zależności pomiędzy obszarem ,zasoby ludzkie” i osiąganymi fazami, zauważyć można m.in. co następuje [Kerremans, 2008, s. 7-14]:

Faza 1 - Pracownicy są głównie zainteresowani spełnieniem oczekiwań w odniesieniu do bieżącego zarządzania. Nie rozumieją natomiast swojej roli w kompleksowej realizacji procesów.

Faza 2 - Pracownicy właściwie rozumieją jakie pełnią role i obowiązki. Niektórzy pracownicy wzięli udział w warsztatach modelowania procesów i zauważają płynące $\mathrm{z}$ tego tytułu korzyści.

Faza 3 - Pracownicy są przeszkoleni z komunikowania problemów pojawiających się podczas realizacji procesów, a także nauczyli się całościowego patrzenia na proponowane rozwiązania. Każdy pracownik rozumie, jak jego wysiłek przyczynia się do osiągnięcia celów dotyczących wyników całej organizacji. Niektórzy pracownicy (szczególnie ci w zaawansowanych organizacjach) zaczęli naukę bardziej wyrafinowanych technik optymalizacji, zaczynających się od wizualizacji wyników i przechodzących do dynamicznych porównań rozwiązań alternatywnych.

Faza 4 - Pracownicy potrafią przewidywać wpływ zachodzących zmian poza procesy, w których uczestniczą, oraz poza elementy, których dotyczą procesy. Współpraca i budowanie konsensusu stają się dla pracowników standardem, ponieważ opór wobec zmian jest uważany za nieodpowiedni i nie jest akceptowany w organizacji.

Faza 5 - Pracownicy są bardziej zsynchronizowani z zaleceniami systemowymi i analizami, celem radzenia sobie ze zmianami zachodzącymi w procesie. Pracownicy zdobywają doświadczenie w łączeniu celów z procesami i wyrównywaniu wyjątków i anomalii.

Faza 6 - Pracownicy czują się komfortowo w środowisku ciągłych zmian, a podejmowanie decyzji jest poddawane decentralizacji.

Zaprezentowane modele dojrzałości procesowej organizacji, zarówno te jedno, jak i wielowymiarowe, zostały stworzone typowo z myślą o organizacjach biznesowych. Istnieje możliwość ich wykorzystania przy ocenie dojrzałości procesowej organizacji publicznych, jednak konieczna staje się wówczas ich adaptacja, uwzględniająca specyficzne uwarunkowania funkcjonowania tego typu organizacji.

\footnotetext{
${ }^{2}$ We wcześniejszej wersji modelu skoncentrowano się częściowo na innych obszarach, tzn. na „dopasowaniu strategii”, „kulturze organizacyjnej i przywództwie”, „pracownikach”, „zarządzaniu”, „metodach” oraz „technologii informacyjnej” [Melenovsky, Sinur, 2006, s. 6].
} 


\section{MODELE DOJRZAŁOŚCI PROCESOWEJ ORGANIZACJI PUBLICZNYCH}

W literaturze spotkać można w szczególności modele dojrzałości procesowej organizacji publicznych, które nie obejmują kompleksowo aspektów związanych zarządzaniem procesami, a które koncentrują się przede wszystkim na ocenie i optymalizacji procesów związanych z e-administracją [Krukowski, 2016, s. 168]. Dla przykładu wymienić można model zaproponowany przez K. Layne i J. Lee. Autorzy wyszczególnili cztery poziomy rozwoju e-administracji, tj. (1) katalogowanie, (2) transakcje, (3) integrację pionową oraz (4) integrację poziomą, przy założeniu, że przechodzenie z jednego poziomu na kolejny wiąze sie z z coraz większa złożonościa wykonywanych operacji i ich integracją. $\mathrm{Na}$ poziomie katalogowania tworzona jest strona internetowa organizacji (w odpowiedzi na presję m.in. pracowników, mediów i przede wszystkim społeczeństwa), na której zamieszczane są głównie informacje o danej jednostce i procedurach (sposobie ich realizacji, wymaganych dokumentach, terminach itd.). Na poziomie transakcji (zwanym tez poziomem jednokierunkowej interakcji) pojawia się możliwość realizowania usług dla obywateli w formie elektronicznej, sprowadzająca się do udostępniania usługi pobierania formularzy ze strony i umożliwienia obywatelom przesyłania ich drogą mailową. Poziom integracji pionowej wiąże się z integrowaniem baz danych rożnych organizacji publicznych, które stanowią strony $\mathrm{w}$ realizacji niektórych procesów świadczonych obywatelom, a poziom integracji poziomej odnosi się do powiązania różnych systemów danych, skupiających odrębne grupy realizowanych usług dla obywateli, przez co obywatel zyskuje możliwość ,załatwienia” wielu spraw w jednym miejscu [Layne, Lee, 2001, s. 124].

Podobny model do wyżej scharakteryzowanego stworzony został przez Organizację Narodów Zjednoczonych. Składa się on z pięciu następujących poziomów [Olszak, Ziemba, 2011, s. 256]:

Poziom początkowy - wyraża sie $\mathrm{w}$ statycznej prezentacji najważniejszych informacji na stronach www na temat jednostek administracji publicznej.

Poziom drugi - wiąze sie z pojawieniem dynamicznych stron internetowych i lepszą wizualizacją informacji, co dla organizacji publicznych oznacza ułatwienia modyfikacji zawartości stron internetowych i poprawe ich funkcjonalności.

Poziom trzeci, tzw. „interaktywny” - wyraża się w możliwości pobierania ze stron internetowych formularzy on-line, przesyłania ich po wypełnieniu pocztą elektroniczną i komunikowania sie z z urzędami za pośrednictwem internetu. Poziom czwarty, tzw. „transakcyjny”, wiąze sięz możliwościa załatwiania spraw urzędowych on-line i dokonywania płatności poprzez internet. 
Poziom piąty - wyraża się w pełnej integracji różnych e-usług w obszarze całej administracji publicznej.

Modele dojrzałości procesowej dedykowane organizacjom publicznym zaproponowali także m.in. J. Zwicker, P. Fettke i P. Loos, według których każda usługa publiczna realizowana być powinna w ciągu 48 godzin [Fettke, Zwicker, Loos, 2010, s. 369-395], czy K. V. Andersen i H. Z. Henriksen, którzy zmodyfikowali opisany wcześniej model K. Layne i J. Lee, nazywając go Modelem Przebudowy Procesów Sektora Publicznego (Public Sector Process Rebuilding - PPR) [Andersen, Henriksen, 2006, s. 236].

Warto zwrócić uwagę także na model dojrzałości procesowej zaproponowany w Programie Rozwoju Instytucjonalnego (PRI). Zawarte są w nim warunki, jakie muszą spełnić jednostki (konkretnie Urzędy administracji samorządowej), aby znaleźć się na jednym z pięciu poziomów (nazwanych stadiami) dojrzałości procesowej. Aktualna wersja modelu (z 2015r.) zaprezentowana została w tabeli 2.

Tabela 2. Stadia dojrzałości procesowej zgodnie z metodyką PRI z 2015 r.

\begin{tabular}{|c|c|}
\hline Stadium dojrzałości & Warunek \\
\hline I & $\begin{array}{l}\text { - Urząd i jednostki organizacyjne gminy posiadaja i stosuja procedury } \\
\text { realizacji zadań zgodnie z przepisami powszechnie obowiazującego } \\
\text { prawa, które zapewniają również ciagłość realizacji kluczowych } \\
\text { zadań, } \\
\text { - } \begin{array}{c}\text { Został określony nadzór nad realizacją zadań przez pracowników, } \\
\text { komórki organizacyjne oraz jednostki organizacyjne gminy. }\end{array}\end{array}$ \\
\hline$\|$ & $\begin{array}{c}\text { Zostały zidentyfikowane kluczowe procesy i ich podstawowe } \\
\text { elementy, tj. wejścia, wyjścia i cel procesu, } \\
\text { Została określona odpowiedzialność za prawidłowy przebieg } \\
\text { procesów kluczowych. }\end{array}$ \\
\hline III & $\begin{array}{l}\text { - Opracowane sa szczegółowe opisy procesów kluczowych } \\
\text { zawierające mierniki i etapy realizacji procesu, } \\
\text { Właściciele procesów oraz ich uczestnicy zostali przeszkoleni } \\
\text { - } \quad \text { zakresie zarządzania procesami, } \\
\text { Opracowano karty usług dla klientów i sposoby dokumentowania } \\
\text { realizacji procesów, } \\
\text { - Prowadzone są cykliczne działania z zakresu zarządzania } \\
\text { ryzykiem w zakresie realizacji procesów (identyfikacja, analiza } \\
\text { i reakcja na ryzyko). }\end{array}$ \\
\hline
\end{tabular}




\begin{tabular}{|c|c} 
Został wdrożony lub został certyfikowany system zarzadzania \\
jakością spełniający wymagania normy ISO 9001, \\
Prowadzone są regularne szkolenia pracowników w zakresie \\
zarządzania i doskonalenia procesów, \\
Część rozwiązań stosowanych w urzędzie została wdrożona \\
także w jednostkach organizacyjnych gminy, \\
Przeprowadzana jest cykliczna ocena efektów funkcjonowania \\
systemu zarządzania procesami oraz wszystkich narzędzi \\
i procedur systemu.
\end{tabular}

Źródło: opracowanie własne na podstawie [Bober, Zawicki, 2015, s. 60-62].

\section{PODSUMOWANIE}

Koncepcja zarządzania procesami, mimo prawie 40-letniego rodowodu, wciąż jest rozwijana na podstawie badań naukowych i wniosków płynących z praktyki zarządzania. Należy się spodziewać, iż jej popularność szybko nie przeminie, wobec wielu korzyści jakie przynosi wykorzystanie charakterystycznych dla tej koncepcji metod i technik zarządzania. Potrzebne będą więc także i modele dojrzałości, za pomocą których określić można poziom zaawansowania organizacji $\mathrm{w}$ realizacji koncepcji zarządzania procesami, a także poznać założenia (czynniki, warunki), które po wdrożeniu do organizacji pozwolą na osiągnięcie przez nie wyższych poziomów dojrzałości procesowej i tym samym na czerpanie z tego tytułu szerszego spektrum korzyści.

Zaprezentowane $\mathrm{w}$ artykule modele stanowią tylko wycinek dostępnych modeli dojrzałości procesowej organizacji, uznać je można jednak za reprezentatywne w swoich grupach (jednowymiarowych, wielowymiarowych, 
czy tych dedykowanych organizacjom publicznym). Szczególnie w tej ostatniej grupie zauważyć można istniejący potencjał dla stworzenia kolejnych modeli, które w pełni oddawać będą specyfikę dynamicznych uwarunkowań funkcjonowania organizacji publicznych.

\section{LITERATURA}

Andersen K. V., Henriksen H. Z., (2006), E-government maturity models: Extension of the Layne and Lee model, „Government Information Quarterly”, $\mathrm{nr} 23$.

Bitkowska A., (2009), Zarządzanie procesami biznesowymi w przedsiębiorstwie, Vizja Press\&IT, Warszawa.

Bitkowska A., Kolterman K., Wójcik G., Wójcik K., (2011), Zarządzanie procesami w przedsiębiorstwie. Aspekty teoretyczno-praktyczne, Wydawnictwo Difin, Warszawa.

Bober J., Zawicki M. (2015), Analiza instytucjonalna gminy z ocena realizacji standardów kontroli zarządczej. Metoda Planowania Rozwoju Instytucjonalnego, Małopolska Szkoła Administracji Publicznej Uniwersytetu Ekonomicznego w Krakowie, Kraków.

Brajer-Marczak R., (2010), Efektywność organizacji z perspektywy modelu dojrzałości procesowej, „Zarządzanie i Finanse. Zeszyty Naukowe”, t. 3, nr 1.

Chrapko M., (2010), CMMI - Doskonalenie procesów w organizacji, Wydawnictwo Naukowe PWN, Warszawa.

Fisher D., The Business Process Maturity Model. A Practical Approach for Identifying Opportunities for Optimization, Online, http://www.bptrends.com/publicationfiles/10-04\%20ART\%20 BP\%20Maturity\%20Model\%20-\%20Fisher.pdf [15.03.2017].

Gabryelczyk R., (2016), Does Grade Level Matter for the Assessment of Business Process Management Maturity?, „Our Economy”, nr 62(2).

Grajewski P., (2007), Organizacja procesowa, PWE, Warszawa.

Grela G., (2013), Ocena poziomu dojrzałości procesowej organizacji, „Nierówności Społeczne a Wzrost Gospodarczy", nr 35.

Hammer M., (2007), The Process Audit, „Harvard Business Review”, nr 4(85).

Jurczuk A., (2013), Procesowa mapa drogowa doskonalenia organizacji z wykorzystaniem modelu $C M M I-D E V$, ,Economics and Management”, $\mathrm{nr} 4$.

Kalinowski T. B., (2011), Modele oceny dojrzałości procesów, „Acta Universitatis Lodziensis”, nr 258.

Kerremans M., Maturity Assessment for Business Process Improvement Leaders: Six Phases for Successful BPM Adoption, „Gartner”, 03.09.2008 r.

Kohlegger M., Maier R., Thalmann S., Understanding Maturity Models. Results of a Structured Content Analysis, Proceedings of I-KNOW '09 and I-SEMANTICS '09 Conference, 2-4 Września 2009, Graz, Austria.

Krukowski K., (2006), Kulturowe uwarunkowania dojrzałości procesowej Urzędów Miast, Wydawnictwo Naukowe Uniwersytetu Mikołaja Kopernika, Toruń.

Layne K., Lee J., (2001), Developing Fully Functional e-Government: A Four Stage Model, „Government Information Quarterly", nr 18(2).

Lee J., Lee D., Kang S., (2007), An Overview on the Business Process Maturity Model, „Advances in Web and Network Technologies, and Information Management", t. 4537.

Melenovsky M.J., Sinur J., BPM Maturity Identifies Six Phase for Successful BPM adoption,,Gartner”, 18.10.2016 r.

Olszak C. M, Ziemba E., (2011), Rozwój e-administracji. Rodzaje i poziomy dojrzałości e-ustug publicznych $w$ regionie śląskim, „Zeszyty Naukowe Uniwersytetu Szczecińskiego. 
Ekonomiczne Problemy Usług", nr 651(68).

Rosemann M., de Bruin T., (2005), Towards a business process management maturity model, „Proceedings of the thirteenth European Conference on Information Systems (ECIS)", z. 37.

Rosemann M., de Briun T., Application of a Holistic Model for Determining BPM Maturity, Online, http://www.bptrends.com/bpt/wp-con-tent/publicationfiles/02\%2D05\%20WP\%20 Application\%20of\%20a\%20Holistic\%20Model\%2D\%20Rosemann\%2DBruin\%20 $\% 2$ D...\%2Epdf [15.03.2017].

Röglinger M., Pöppelbuß J., Becker J., (2012), Maturity models in business process management, „Business Process Management Journal”, nr 2(18).

Tarhan A., Turetken O., Reijers H. A., (2016), Business process maturity models: A systematic literature review, „Information and Software Technology”, $\mathrm{nr} 75$.

Zwicker J., Fettke P., Loos P., (2010), Business Process Maturity in Public Administrations, [w:] J. vom Brocke, M. Rosemann (red.), Handbook on Business Process Management 2, Springer-Verlag, Berlin Heidelberg.

\section{PROCESS MATURITY MODELS OF ORGANIZATIONS}

Abstract: The article addresses the issue of process maturity of an organization. The essence of the process maturity and the differences between process-mature and process-immature organization were presented. Also, selected models of process maturity of an organization, both one-dimensional and those using a holistic approach (multidimensional) were introduced. Special place was dedicated to the models of process maturity of public organizations.

Keywords: process maturity of an organization, process maturity models, process maturity models of public organizations. 
